\title{
Juokse, jotta pysyt paikallasi
}

\author{
KATARIINA PONTEVA (2012): \\ Muutoksessa. \\ Sanoma Pro Oy, 1. painos. $117 \mathrm{~s}$. \\ ISBN: 978-952-63-0051-1.
}

Katarina Pontevan teos tarkastelee organisaatiomuutoksia käytännöllisestä näkökulmasta. Siinä esitellään viisi erilaista muutosprosessia, joita lähestytään organisaatioiden eri tasoilla toimivien työntekijöiden muutostarinoiden kautta. Tarinat on koottu haastattelemalla. Tapaukset ovat todellisia ja kirjassa mainitaan organisaatiot myös nimeltä.

Ponteva on alun perin kasvatustieteilijä ja tekniikan lisensiaatti, joka väitteli tohtoriksi vuonna 2009 hallintotieteistä. Väitöskirjan aiheena oli organisaatiomuutos työntekijän kokemana. Nykyisin kirjoittaja toimii konsulttina.

\section{ORGANISAATIOMUUTOS AJAN ILMIÖNÄ}

Muutoksen ja muutoksen johtamisen teemat ovat olleet alan kirjallisuudessa trendikkäitä tutkimuskohteita jo 1990-luvulta alkaen, ja nykyinen organisaatioelämä tuntuu olevan tulvillaan erilaisia muutoksen johtamisen oppikirjoja ja koulutuksia. Muutoksen johtamisesta näyttääkin rakentuvan oma johtamisen osa-alueensa, joka ei integroidu niin sanottuun normaaliin arjen johtamiseen.

Organisaatiopuheeseen tuntuu vakiintuneen ajatus jatkuvasta muutoksesta ja sen välttämättömyydestä. Johdon puhe siitä, että on "juostava entistä kovempaa pysyäkseen paikallaan" herättää monissa työntekijöissä turhautumista, kiukkua ja usein myös ahdistusta.

Katariina Ponteva on ottanut vastaan mielenkiintoisen haasteen osoittaessaan sanansa kaikille työntekijöille, ei vain johdolle tai henkilöstöalan ammattilaisille. Kirjan tapausesimerkkejä ajatellen tämä tarkoittaa muun muassa sairaanhoitajia, siivoojia ja opettajia.

\section{VIISI ERILAISTA TAPAUSTA}

Kirjan mielenkiintoisinta antia ovat todelliset tapauskuvaukset. On hienoa, että kirjoittaja on saanut or- ganisaatioilta luvan käyttää niitä muutostyöskentelyn esimerkkeinä, niin hyvässä kuin pahassa. Ponteva onnistuu tuomaan esimerkit lähelle lukijaa ja välttämään turhaa teoretisointia.

Teoksessa esitellään viisi vuosina 2003-2011 toteutettua organisaatiomuutosta. Ensimmäinen muutostarina kuvaa Helsingin ja Uudenmaan sairaanhoitopiirin Meilahden tornisairaalan remontista aiheutunutta myllerrystä ja toinen tarina Pirkanmaan ja Tampereen ammattikorkeakoulujen yhdistymistä Suomen toiseksi suurimmaksi ammattikorkeakouluksi. Kolmas tapaus on tälle ajalle tyypillinen kuntaliitos, jossa Merimasku, Rymättylä ja Velkua liittyivät osaksi Naantalia. Neljäs tapaus on sama, jota Ponteva tutki väitöskirjassaan eli Helsingin kaupungin omistaman liikelaitoksen Palmian luominen useista kaupungin eri virastojen alaisista palvelukeskuksista. Viimeisessä tapauksessa vertaillaan kahden eri kunnan, Naantalin ja Helsingin, erilaisia tapoja organisoida päivähoidon hallinto.

Tapausesimerkit ovat kiinnostavia ja niiden voidaan katsoa koskettavan paitsi organisaatioiden työntekijöitä, myös kymmeniä tuhansia asiakkaita potilaina, opiskelijoina tai kunnan palvelujen käyttäjinä. Tämä tekee teoksesta myös yleiskiinnostavan. Toisaalta esimerkkikuvauksia ja niistä johdettuja analyyseja vaivaa hienoinen pinnallisuus. Monimutkaisia prosesseja sekä ihmisten monenlaisia kokemuksia ja tunteita on kirjassa tiivistetty reiluun sataan sivuun. Tämä aiheuttaa väistämättä lukijassa tunteen, että tapauksissa on ollut varmasti paljon muutakin kuin nyt raportoitu. Tätä kokemusta vahvistaa se, että monet tapaukset kuvataan päällisin puolin hyvin onnistuneina. Syvällisempään analyysiin päästään oikeastaan vain liikelaitos Palmian tapauksessa, joka toimi myös Pontevan väitöstyön aineistona. 
Toisin kuin muut kirjan tapausesimerkit, päivähoidon hallintoa lyhyesti kuvaava tapaus ei tunnu istuvan kirjan ideaan ja tavoitteeseen. Kuvaus jää irralliseksi ja käsittelee tematiikkaa enemmän hallinnon organisoinnin kuin organisaation muutosprosessin näkökulmasta. Hieman syventämällä muiden neljän tapauksen analyysia ja jättämällä viidennen kokonaan pois, kirjan rakenteesta olisi uskoakseni tullut jäntevämpi.

\section{HENKILÖKOHTAISTA VAI YHTEISÖLLISTÄ?}

Pontevan peruslähtökohta muutostyöskentelyyn ja muutoksen käsittelyyn lähtee ihmisten henkilökohtaisesta kokemusmaailmasta. Hän korostaa johtopäätöksissään tunneälyn merkitystä ja monissa paikoin kirjaa myös positiivisen asenteen tärkeää roolia onnistuneen muutoksen taustalla.

Avainhenkilöiden, muun muassa Naantalin henkilöstöpäällikön, persoonalliset ominaisuudet muutosjohtajana nostetaan esille. Ponteva käyttää analyysin välineenä kehittämäänsä nelikenttää, joka kuvaa työntekijän kokemusmaailmaa ja erilaisia reagointitapoja. Muutosprosessi vaikuttaa siihen, vieraantuuko vai kiinnittyykö työntekijä työhönsä ja etääntyykö vai samaistuuko työntekijä organisaatioonsa. Näin työntekijästä tulee suhteessa muutokseen joko (a) innostunut, (b) kuuliainen, (c) välinpitämätön ja kyyninen tai (d) kapinallinen ja omapäinen.

Yhteisölliset ja kulttuuriset tekijät jäävät teoksessa vähemmälle huomiolle. Vaikka Ponteva korostaakin muutostyöskentelyssä viestintää, tukipalvelujen roolia sekä henkilöstön osallisuutta ja osallistumista suunnitteluun, monet yhteisödynamiikkaan liittyvät asiat jäävät maininnan asteelle. Kiinnostavia teemoja syventää analyysia olisivat olleet esimerkiksi lääkäreiden ja hoitajien välinen dynamiikka, eri organisaatiokulttuurien yhteensovittamiseen liittyvät hyvät käytännöt tai vaikkapa julkisen sektorin ja liiketoiminnan logiikkojen yhteensovittaminen koulutyön arjessa.

Otanpa omasta kokemuksestani esimerkin. Kun kaksikymmentä vuotta sitten fuusioituneiden organisaatioiden työntekijät edelleen puhuvat "meistä" eivätkä tervehdi "muita", onko kyse näiden yksilöiden henkilökohtaisesta asenteesta ja suhteesta muutokseen? Osittain varmaankin kyllä. Toisaalta myös väittäisin, että kyse on jostain hyvin syvällisestä or- ganisaation alitajuntaan kytkeytyvästä ilmiöstä, jossa vaikuttavat arvostukset, ryhmädynaamiset ilmiöt, organisaatiokulttuuri, historia, organisaation ulkoiset ja sisäiset rajat ja niillä toiminen ja monet muut ilmiöt. Perustavaa laatua oleva muutos nostaa nämä kaikki esiin. Onnistuakseen muutosprosessin täytyy käsitellä myös näitä asioita riittävällä tavalla.

Teoksen vahvuus on ehdottomasti tapausesimerkkien konkreettisuus. Kirjassa esitetään myös lukuisia käytännönläheisiä kiteytyksiä ja muistilistoja organisaatiomuutosten toteuttajille. Nämä palvelevat niitä tuhansia johtajia ja esimiehiä, jotka toteuttavat muutostyötä käytännössä organisaatioissa eri puolilla maata. Kirja auttaa myös työntekijöitä näkemään muutostyön kokonaisuuden ja se avaa erilaisia, muun muassa johdon, näkökulmia muutokseen.

Markus Anttila

Toimitusjohtaja, organisaatiokonsultti, työnohjaaja Kehityspiikki Consulting Oy ja Kehityspiikki Tutkimus Oy

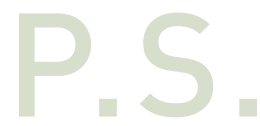

"Ovatko organisaatiomuutokset aikamme ilmiö vai nostetaanko asioita vain enemmän keskusteluun? Monet kokevat, että muutostahti työpaikoilla kiihtyy. Se uhkaa jo vakavasti työhön kytkeytyvää perusturvallisuutta. 1980-luvusta puhutaan "kultaisena kautena", jolloin työssä oli vielä väljyyttä, ja siinä sai keskittyä perustehtäväänsä. Työn rakenteita ei muutettu jatkuvasti. Nuorten ikäluokassa on nyt rakentumassa uudenlainen tapa ajatella työtä. Se perustuu jo lähtökohdiltaan epävarmuuteen ja jatkuvaan muutokseen. Tulevaisuuden trendi voi olla tämä. Tai voihan meille tulla jonkinlainen slow work-liike, joka tuottaa myös työnantajapuolelle uudenlaista tapaa rakentaa vastapainoa hektiselle muutostahdille. Kuka tietää?" 